\title{
Response to Disodium Etidronate Treatment in Three Siblings with Pulmonary Alveolar Microlithiasis
}

\author{
Erkan Cakir $^{\mathrm{a}}$ Ahmet Hakan Gedik ${ }^{\mathrm{a}}$ Ali Özdemir Nur Buyukpınarbasilib $^{\mathrm{b}}$ \\ Mehmet Bilginc Ilker Tolga Ozgen ${ }^{d}$ \\ Departments of a Pediatric Pulmonology, ${ }^{b}$ Pathology, ${ }^{c}$ Radiology and d Pediatric Endocrinology, Faculty of Medicine, \\ Bezmialem Vakif University, Istanbul, and ' Mersin Children's Hospital, Mersin, Turkey
}

\section{Established Facts}

- Pulmonary alveolar microlithiasis (PAM) is a rare chronic genetic lung disease in childhood with no proven therapy.

- The effect of disodium etidronate (DE) treatment on PAM is controversial.

\section{Novel Insights}

- After completion of 1 year of treatment with DE, the 11-year-old boy and one of the twins showed significant improvement in the chest X-ray and high-resolution computed tomography findings, but the same was not observed in the other twin.

- DE may be a treatment option, but further reports are needed.

\section{Key Words}

Pulmonary alveolar microlithiasis · Disodium etidronate . Childhood

\begin{abstract}
Pulmonary alveolar microlithiasis (PAM) is a rare chronic genetic lung disease in childhood with no proven therapy. It is characterized by the deposition of calcium phosphate microliths within the alveolar air spaces. The effect of disodium etidronate (DE) treatment on PAM is controversial. We report 3 siblings (an 11-year-old boy and 4-year-old twin girls) with PAM diagnosed by chest X-ray, thoracic high-resolution
\end{abstract}

(c) 2015 S. Karger AG, Basel

$0025-7931 / 15 / 0896-0583 \$ 39.50 / 0$ computed tomography, technetium-99m bone scan and bronchoalveolar lavage fluid findings. After the administration of DE ( $200 \mathrm{mg} /$ day) for a 1-year period, 2 siblings showed radiological improvement, while 1 sibling did not. No drug side effects were observed within the treatment period.

(c) 2015 S. Karger AG, Basel

\section{Introduction}

Pulmonary alveolar microlithiasis (PAM) is a rarely seen chronic lung disease in childhood characterized by the deposition of calcium phosphate microliths within

\section{KARGER 125}

E-Mail karger@karger.com www.karger.com/res 
the alveolar air spaces [1]. Familial occurrence has been described, supporting an autosomal recessive inheritance. Most cases of PAM have been reported in Europe (especially in Turkey and also in Italy) followed by Asia and America [2]. Recently, the SLC34A2 gene, which encodes the type II sodium phosphate cotransporter and is specifically expressed in type II alveolar cells, has been found to be responsible for the disease [3]. Children with PAM are usually asymptomatic, even in the case of extensive radiological involvement, and their disease is often discovered incidentally [1]. Coughing and dyspnea are the most common presenting symptoms, which usually occur late in the course of the disease. A diagnosis is made on the basis of characteristic chest radiographic (bilateral 'sandstorm' appearance, i.e. micronodular calcified densities known as microliths or calcospherites), thoracic high-resolution computed tomography (HRCT; scattered micronodules, interlobular septal thickening, subpleural septal thickening and cystic changes as well as some areas of ground-glass opacity) and technetium-99m $\left({ }^{99 \mathrm{~m}} \mathrm{Tc}\right)$ diphosphonate bone scintigraphic findings [2]. Identification of microliths in the expectorated sputum or bronchoalveolar lavage (BAL) fluid is diagnostic [4].

Little is known about the clinical course and treatment results of PAM. Corticosteroids, chelating agents and therapeutic BAL have demonstrated no benefit in the treatment of PAM [3]. A few case reports of disodium etidronate (DE) drug therapy, which has an inhibitory effect on the microcrystal growth of hydroxyapatite, have shown success in the course of the disease [5-8]. However, the role for the use of this mode of treatment remains to be proven. The purpose of the present report is to discuss the effectiveness of the 1-year DE treatment in our 3 patients with PAM.

\section{Case Reports}

An 11-year-old boy was referred to our clinic for an evaluation of suspected miliary tuberculosis. The patient had a 9-month history of antituberculosis treatment, which began at 4 years of age. He was asymptomatic and appeared to be healthy. His laboratory analysis did not support tuberculosis, and he had no history of any tuberculosis contact. The chest X-ray, thoracic HRCT and ${ }^{99 \mathrm{~m} T c}$ diphosphonate bone scintigraphic findings showed bilateral, sandlike, micronodular calcified densities concentrated in the lower two thirds of the lung. BAL fluid revealed typical microliths (calcospherites) consistent with the diagnosis of PAM (fig. 1). His pulmonary function test, vitamin $\mathrm{D}_{3}$ and parathyroid hormone levels, urinary tract ultrasonography and echocardiography were all normal. A subsequent investigation of the family members revealed that their 4 -year-old twin girls also had PAM. The SLC34A2 gene mutation [c.226C > T (Gln76Term)] was homozygous in all siblings.

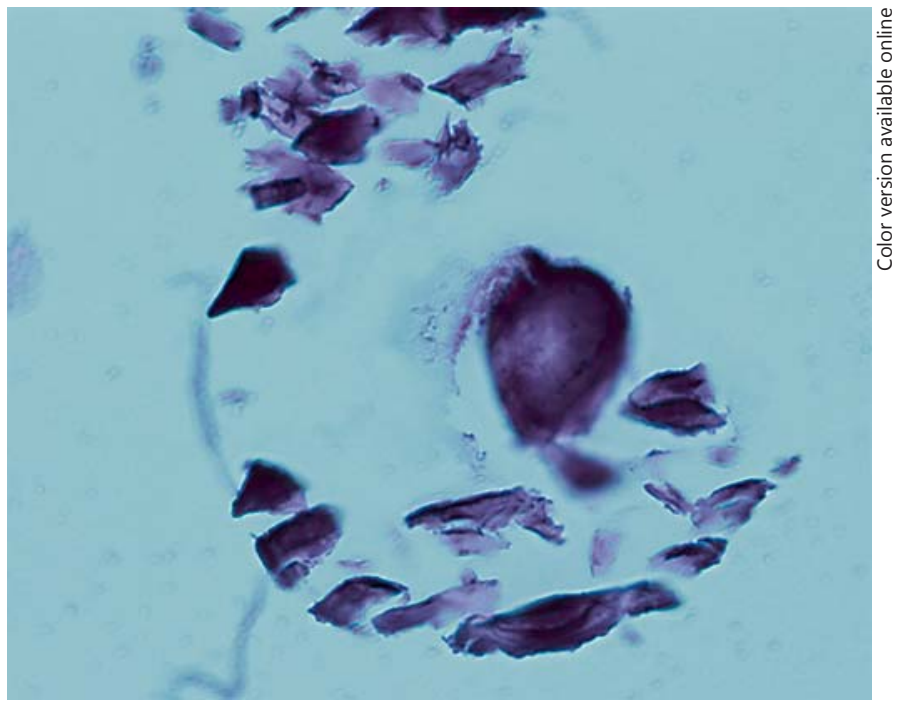

Fig. 1. Histopathological appearance in the BAL fluid indicating typical microliths (calcospherites). HE. $\times 400$.

The family consented to the DE treatment for all siblings. After completion of a 1-year treatment cycle with DE, the 11-year-old boy and one of the twins showed significant improvement in their chest X-ray and HRCT findings; however, this was not observed in the other twin (fig. 2). All siblings are still receiving DE drug therapy and are being monitored every 2 months for drug side effects by analyzing their blood calcium and phosphate levels and the urine calcium/creatine ratio. Thus far, no adverse drug reaction has been detected.

\section{Discussion}

PAM is a rare disease with no proven therapy. There is no known treatment including corticosteroids, chelating agents or therapeutic BAL that influences the course of PAM [2]. Lung transplantation is the only option in severe cases. As a bisphosphonate, DE treatment has been reported to be effective in a few patients with PAM $[6,7]$. This drug is well known in the treatment of Paget's disease, heterotopic ossification and hypercalcemic states due to malignancy [5]. It can inhibit the formation, growth and dissolution of hydroxyapatite crystals and their amorphous precursors by chemisorption to calcium phosphate surfaces. DE was first proposed to be beneficial in the treatment of PAM following both clinical and radiological findings in a case report by Gocmen et al. [6] in 1992. Later, the same group reported early and longterm beneficial effects of DE in their 2 PAM cases $[7,8]$. In one of the cases, the patients had DE-related rickets 
Fig. 2. Radiological findings of the patients before and after 1 year of treatment. $\mathrm{Pa}$ tient 1: 11-year-old boy who responded to therapy. Before: tiny, miliary consolidations, primarily in an alveolar setting, can be seen bilaterally in both two thirds of the lungs. After: regression of the lesions. $\mathrm{Pa}$ tient 2: twin who responded to therapy. Before: bilateral perihilar consolidations and interstitial fibrotic changes can be seen. After: regression of the lesions. Patient 3: twin who did not respond to therapy. Before: bilateral perihilar consolidations and interstitial fibrotic changes can be seen. After: no regression of the lesions.

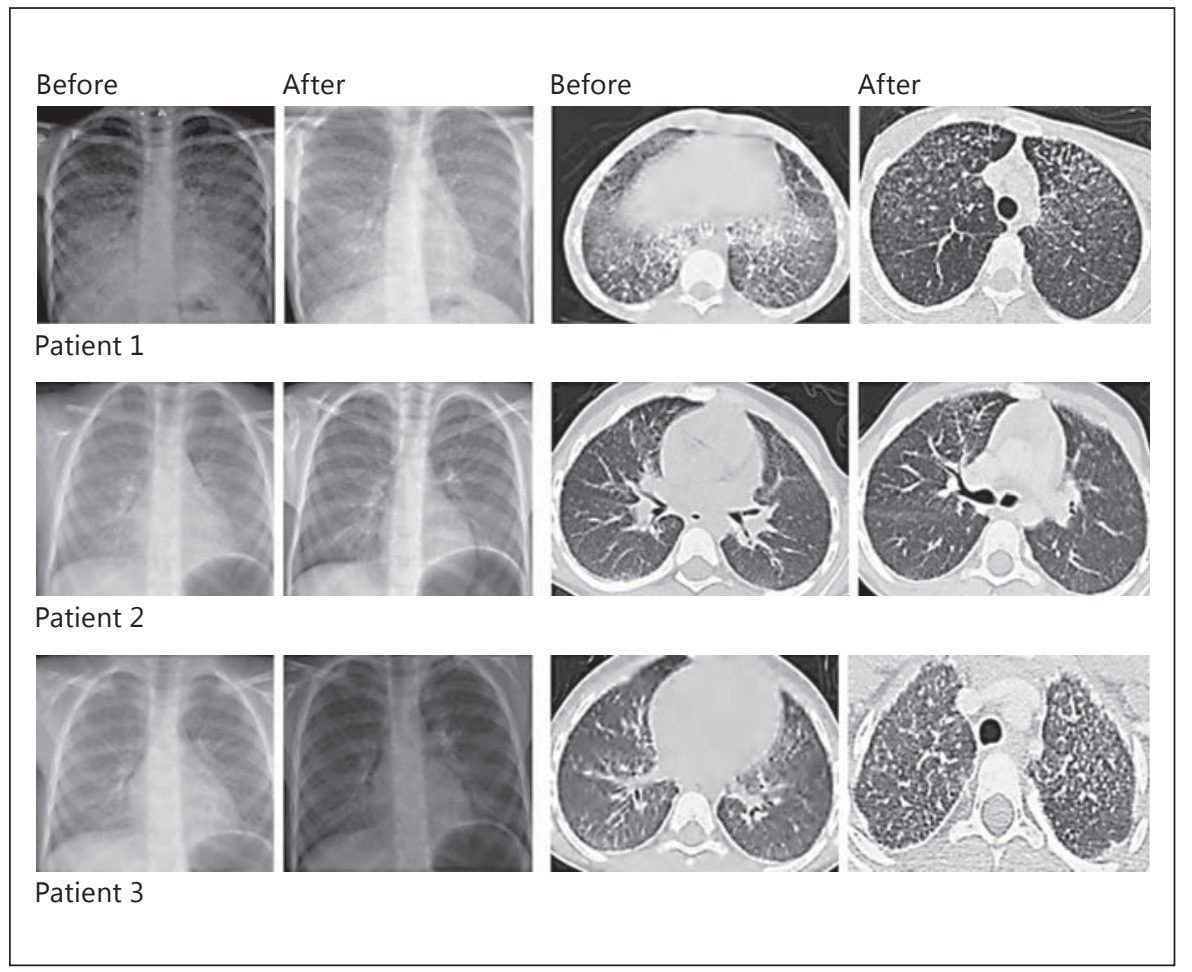

Table 1. Effect of DE treatment in children with PAM

\begin{tabular}{|c|c|c|c|c|}
\hline Authors & Patient age/sex & Dosage & Duration & Response to treatment \\
\hline Gocmen et al. [6], 1992 & 3.5 years/female & 15 mg/kg/day & 36 months & response \\
\hline Mariotta et al. [9], 1997 & & 300 mg/day & 6 months & no response \\
\hline Jankovic et al. [10], 2002 & 8.5 years/female & $400 \mathrm{mg} /$ day & 18 months & no response \\
\hline Özçelik et al. [7], 2002 & $\begin{array}{l}5 \text { years/female } \\
9 \text { years/female }\end{array}$ & $\begin{array}{l}200 \mathrm{mg} / \text { day } \\
200 \mathrm{mg} / \text { day }\end{array}$ & $\begin{array}{r}9 \text { years } \\
11 \text { years }\end{array}$ & $\begin{array}{l}\text { response } \\
\text { response }\end{array}$ \\
\hline Özçelik et al. [8], 2010 & 9 years/female & $10 \mathrm{mg} / \mathrm{kg} /$ day & 12 months & response \\
\hline Cakir et al., this study & $\begin{array}{l}11 \text { years/male } \\
4 \text { years/female } \\
4 \text { years/female }\end{array}$ & $\begin{array}{l}10 \mathrm{mg} / \mathrm{kg} / \text { day } \\
10 \mathrm{mg} / \mathrm{kg} / \text { day } \\
10 \mathrm{mg} / \mathrm{kg} / \text { day }\end{array}$ & $\begin{array}{l}12 \text { months } \\
12 \text { months } \\
12 \text { months }\end{array}$ & $\begin{array}{l}\text { response } \\
\text { response } \\
\text { no response }\end{array}$ \\
\hline
\end{tabular}

which disappeared after cessation of the drug. Then, DE was administered as a 15-day treatment schedule every 2 months. Subsequently, a treatment schedule every 3 or 4 months showed the same benefit and improvement in both clinical and HRCT findings in this patient. Interestingly, 11 years after cessation of the drug treatment, their first patient was clinically stable including chest X-ray and HRCT findings. In the literature, there are also 2 case reports showing no significant clinical or radiological improvement with DE treatment. Mariotta et al. [9] admin- istered DE to their patient for 6 months in the late stage of the disease with no benefit. Jankovic et al. [10] used the drug on an 8.5-year-old girl with PAM for 18 months in a nonadvanced pulmonary involvement and observed no significant or radiological benefit. Table 1 summarizes the previously mentioned reports of the effectiveness of DE treatment.

Herein, we report the early results of the efficacy of DE treatment in 3 siblings with PAM. After a 1-year treatment period, 2 of our patients showed significant radio- 
logical benefit while 1 did not, without considerable drugrelated side effects. The patients are still receiving DE treatment and are followed up every 2 months. Our report supports the use of this therapy for PAM. More cases using this treatment are needed in order to clarify the benefit of the drug. It is also unclear how long patients should receive the DE therapy to maintain clinical and radiological stability or to conclude that the treatment has been a failure. Thus, long-term follow-up of these patients is critical in the treatment period.

\section{References}

1 Mariotta S, Ricci A, Papale M, De Clementi F, Sposato B, Guidi L, Mannino F: Pulmonary alveolar microlithiasis: report on 576 cases published in the literature. Sarcoidosis Vasc Diffuse Lung Dis 2004;21:173-181.

-2 Castellana G, Lamorgese V: Pulmonary alveolar microlithiasis. Respiration 2003;70:549-555.

3 Corut A, Senyigit A, Ugur SA, Altin S, Ozcelik U, Calisir H, Yildirim Z, Gocmen A, Tolun A: Mutations in SLC34A2 cause pulmonary alveolar microlithiasis and are possibly associated with testicular microlithiasis. Am J Hum Genet 2006;79:650-656.

4 Poletti V, Costabel U, Casoni GL, Bigliazzi C, Drent M, Olivieri D: Rare infiltrative lung dis- eases: a challenge for clinicians. Respiration 2004;71:431-443.

5 Reszka AA, Rodan GA: Mechanism of action of biphosphates. Curr Osteoporos Rep 2003; 1:45-52.

6 Gocmen A, Toppare MF, Kiper N, Buyukpamukcu N: Treatment of pulmonary alveolar microlithiasis with a diphosphonate - preliminary results of a case. Respiration 1992; 59:250-252.

-7 Özçelik U, Gülsün M, Göçmen A, Arıyürek M, Kiper N, Anadol D, Çobanoğlu N: Treatment and follow-up of pulmonary alveolar microlithiasis with disodium etidronate: radiological demonstration. Pediatr Radiol 2002;32:380-383.
-8 Özçelik U, Yalcin E, Ariyurek M, Ersoz DD, Cinel G, Gulhan B, Kiper N: Long-term results of disodium etidronate treatment in pulmonary alveolar microlithiasis. Pediatr Pulmonol 2010;45:514-517.

-9 Mariotta S, Guidi L, Mattia P, Torrelli L, Pallone G, Pedicelli G, Bisetti A: Pulmonary microlithiasis: report of two cases. Respiration 1997;64:165-169.

10 Jankovic S, Pavlov N, Ivkosic A, Erceg I, Glavina-Durdov M, Tocilj J, Dragisic-Ivulic S, Primorac D: Pulmonary alveolar microlithiasis in childhood: clinical and radiological follow-up. Pediatr Pulmonol 2002;34:384387. 